\title{
The First Aerial Journey from Portugal to Macau
}

\author{
Fernando M. S. P. Neves, Jorge M. M. Barata, André R. R. Silva \\ Aerospace Sciences Department, Universidade da Beira Interior, Covilhã, Portugal \\ Email: fernandomneves@gmail.com
}

How to cite this paper: Neves, F.M.S.P., Barata, J.M.M. and Silva, A.R.R. (2016) The First Aerial Journey from Portugal to Macau. Open Journal of Applied Sciences, 6, 728750.

http://dx.doi.org/10.4236/ojapps.2016.610066

Received: July 8, 2016

Accepted: September 24, 2016

Published: September 27, 2016

Copyright $\odot 2016$ by authors and Scientific Research Publishing Inc. This work is licensed under the Creative Commons Attribution International License (CC BY 4.0).

http://creativecommons.org/licenses/by/4.0/

\begin{abstract}
On 1920, Brito Pais and Sarmento Beires tried an unsuccessful flight attempt from Amadora, Lisbon to Madeira Island onboard an airplane Breguet XIV A2, named "Cavaleiro Negro". Despite the scarce means of navigation both navigators managed to reach Madeira, which failed to land due to dense fog. On their way back after 8 hours of flight time, they alight at the Atlantic Ocean for lack of fuel and were rescued at about $500 \mathrm{~km}$ from Lisbon. On 1922, Gago Coutinho and Sacadura Cabral conducted the First Aerial Cross of the South Atlantic, flying from Lisbon to Rio de Janeiro. The Portuguese Aeronautics rejoiced auspicious days that time, with its aviation pioneers trying consecutively to reach more distant places along intercontinental flights. On 1923, Gago Coutinho and Sacadura Cabral were contemplating to perform an Around the World Flight. However, Sacadura died in 1924, while piloting an airplane acquired for the circumnavigation voyage. Later on 1924 the pilots Brito Pais and Sarmento Beires idealized the conducting of an aerial flight from Lisbon to Macau as an aspiration for a future Portuguese Around the World Flight attempt: on 7 April 1924, those pilots departed from Vila Nova de Milfontes in a Breguet XIV Bn2 airplane, starting their Journey to Macau. During a flight stage on 7 May an engine failure forced them to crash the airplane at India; on 30 May, both pilots managed to continue the Voyage in a De Havilland DH9 aircraft before being forced to end their attempt in 20 June in flying over Macau. A typhoon hindered their efforts to land and the airplane was crash landed in Chinese Territory about 800 meters from the Hong Kong Border. On 25 June 1924, they were shuttled back to Macau by boat. Brito Pais, Sarmento Beires and Manuel Gouveia returned to Portugal, via North America, visiting several Portugueses nuclei at China, Japan, United States and England. They went to Portugal on 9 September, after having flown a total of $16,760 \mathrm{~km}$ in 117:41 h facing often extremely adverse atmospheric conditions, sandstorms and inaccurate navigation maps.
\end{abstract}

\section{Keywords}

Sarmento Beires, Brito Pais, Raid Lisboa-Macau 1924 


\section{Introduction}

On 18 April 1920 at 10:00 h, Brito Pais and Sarmento Beires tried an unsuccessful flight attempt from Amadora to Madeira Island; this flight was performed with the consent of the Base Commander Major Antonio Maya, however, without consent or even permission of the Minister of War, Colonel Hélder Ribeiro; so, both pilots took off clandestinely from Amadora. Despite the scarce means of navigation, pilots flew over Madeira Island which failed to land due to dense fog and after 8 hours of flight time, they alighted the aircraft at the Atlantic Ocean due lack of fuel. Later that day, they were located and rescued by the Gambia River ship near the coordinates $35^{\circ} \mathrm{N} 13^{\circ} \mathrm{W}$, about $500 \mathrm{~km}$ from Lisbon. Their clandestine voyage led to several contradictions between the attempts of punishment and praise. And by the pressure of popular enthusiasm stimulated by the Portuguese newspaper Jornal de Notícias, they were never punished even ending up being lauded in Army Order of 10 November 1920. This flight was also tapped for a campaign criticizing the lack of support to military aviation at Portugal [1] [2]. On December 1920, both pilots were consulted about their airplane preferences, especially regarding an Aerial Circumnavigation Flight Attempt. After studied the characteristics of all available aircrafts, they concluded that the Breguet XVI was at the time the apparatus that offered best conditions: security, because of its Renault engine of 300 hp, as well as load capacity. This preference was then communicated to commissioned Officers, who followed the appropriate steps for the immediate purchase of such airplane: a public subscription organized by Pinheiro Corrêa, Jardim da Costa and Bensabat Levy. On June 1921 an aircraft of this type was delivered disassembled at the Amadora hangars, starting immediately to be assembled and adapted for Intercontinental Voyages purposes. The adaptation consisted on removing all the useless military cargo and by installing additional fuel tanks for greater flight stages range. On late August 1921, Brito Pais chose to name this airplane and written on the fuselage skin the Lusíadas verse: "Esta é a ditosa PÁTRIA minha amada" [This is my beloved and blissful MOTHERLAND] (Lusíadas is a Portuguese epic poem written by Luís Vaz de Camões, mainly on scope of a fantastic interpretation of the Portuguese Voyages of Discovery during $15^{\text {th }}$ and $16^{\text {th }}$ centuries; The Lusiads work was concluded in 1556 and first printed in 1572). The aircraft was christened simply by the name of "Pátria" (Figure 1). On the morning of 22 September 1921 the "Pátria" first flight was carrying out over 30 minutes at the Lisbon surroundings. On November of that year, a hurricane partially destroyed the airplane [1]. On 8 December 1921, the Director of Military Aeronautics, Lieutenant Colonel António Freitas Soares Maya, called for a meeting with the Technical Committee of Military Aeronautics with the objective to expose this airplane main goal. The Portuguese Government paid all airplane's repairs; damage repairs began in June 1922 with an unexplained delay from the manufacturer company. Meanwhile, between 30 March and 17 June 1922, Gago Coutinho and Sacadura Cabral performed the First Aerial Crossing of the South Atlantic [2]-[12]. That fact led to amend the initial route (initially Rio de Janeiro) destination for this aircraft along this Journey.

While the aircraft was being rebuilt, Brito Pais and Sarmento Beires had the idea of 


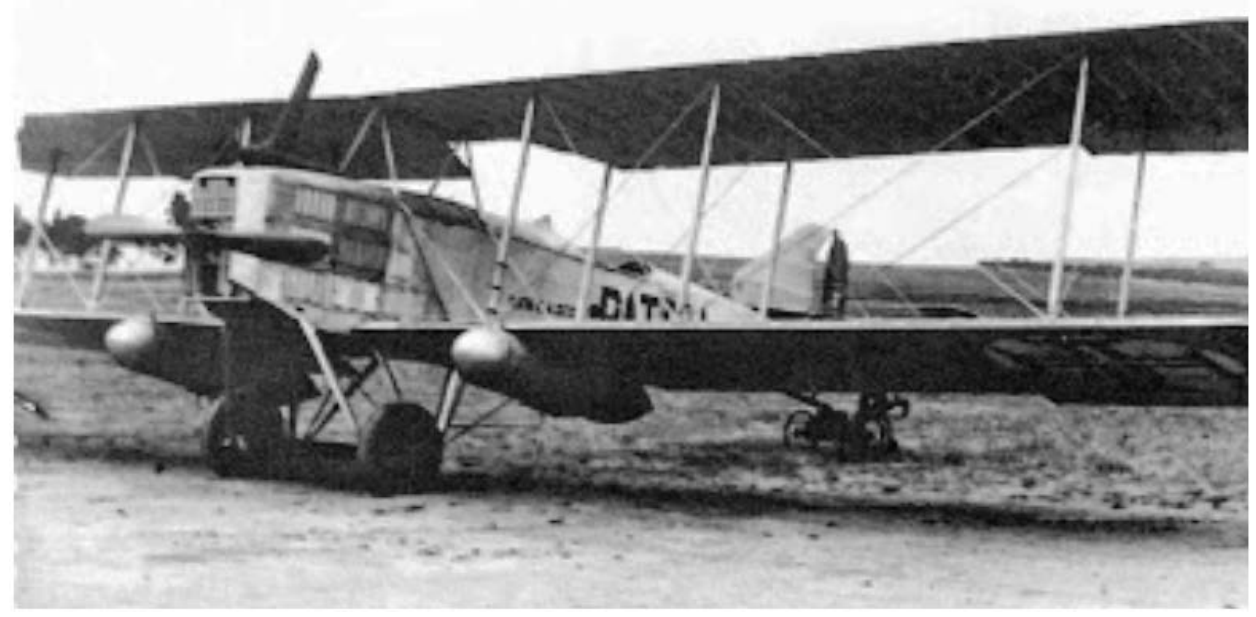

Figure 1. Photo of the airplane "Pátria" [2].

under taking an aerial journey form Lisbon to India for historical affinity; this journey was later lengthened to Macau. This Intercontinental Flight had the aspiration of a preparation voyage for a future Portuguese around the World Flight, a desire chased by Sacadura Cabral [2] [5] [6] [11]-[15].

\section{Brito Pais and Sarmento Beires Require the Usage of Aircraft "Pátria"}

The Director of Military Aeronautics met with the Technical Committee of Military Aeronautics on 4 April 1923; on table was discussed a document request in which both pilots Brito Pais and Sarmento Beires asked permission to use the "Pátria" for an Intercontinental Journey purpose. The Technical Committee approved the document and further agreed to grant to Sarmento Beires and Brito Pais a priority of "Pátria" airplane usage on an Aerial Circumnavigation Flight Attempt. On the morning of 28 June 1923 the airplane crashes on the ground and became seriously damaged. Meanwhile the Minister of War had again consulted the Technical Commission on 3 August and realized that the first stage of this trip should not be attempted. Damage repairs were started immediately and on 26 October the airplane was able to accomplish a 1:05 h flight toward Vila Nova de Milfontes in order to perform loading tests. Bureaucratic reasons would again prevent the aircraft loading tests until 28 January 1924. From 29 to 31 January 1924 were carried out load tests. The aircraft empty weight was $1,350 \mathrm{~kg}$. Talks with Breguet enterprise guarantee that they already tested this airplane at France with $37 \mathrm{~kg} / \mathrm{m}^{2}$ of lift surface; since total wing area was $73.5 \mathrm{~m}^{2}$ the airplane would be structured to withstand a $2,719.5 \mathrm{~kg}$ of total weight. Breguet enterprise guarantees also that the airplane would be structured to withstand a $40 \mathrm{~kg} / \mathrm{m}^{2}$ of lift surface. Load tests were carried out in several flights for different scenarios: 960, 1,100 and 1,450 kg of payload. On flight test with $1,450 \mathrm{~kg}$ of payload the airplane ran 600 meters before the take-off and behave normally along 1:15 h of flight maneuvers and reaching without difficulty 
the maximum desired altitude of 1,000 meters. Finally, all bureaucratic adversities were overcome on 31 March 1924. Following the scheduled idea, the mechanic Manuel Gouveia traveled to Tunis, where he would began his flight stages onboard the "Pátria" with rest of the crew: Brito Pais and Sarmento Beires [1]. To the Portuguese Government, the Intercontinental Flight success possibilities related to the aircraft had been demonstrated; the total success would rely the on crew and on their luck. At that time, the maneuvers of airplane take-off and landing were a real adventure: beyond lack of onboard instruments, rudimentary aerodynamics and aircraft structures, the airfields (when worthy that name) were poorly prepared for land, making thus the pioneering aviation even more remarkable [1] [2].

\section{Crew Biographical Notes}

\subsection{Brito Pais}

António Jacinto da Silva Brito Pais (Figure 2) (Colos, Vila Nova de Milfontes-15 July 1884, mid-air collision at Algueirão, Portugal-22 February 1934) joined the Army School in 1907, where he graduated with Weapon Infantry acquirements. Later he paid its duty service as Officer Cadet at the Batalhão de Caçadores 5 [Hunter Battalion 5] in Lisbon and was promoted to the rank of Lieutenant in November 1910 Shortly after he was appointed to serve its military duties at the Niassa Military Divison (Mozambique), from where he returned in 1912 due to illness. From 1914 to 1915 he made part of the Military Companies campaign at southern Angola, under the command of General Pereira d'Eça. In 1917 he embarked for France as part of Battalion 15 incorporated in the Corpo Expedicionário Português-CEP [Portuguese Expeditionary Corps] [3]. He fought at the battle's frontlines, being awarded with the both Portuguese Cruz de Guerra [War Cross] and the Cruz da Ordem Militar da Torre e Espada [Cross of the Military Order of the Tower and Sword]. He was also awarded with the Honor order of the Ordre National de la Légion d'Honneur [French National Order of the Legion of Honor]. He attended the Military Aviation School of Avord, getting the pilot's brevet on 29 November 1917. In 1920 along with Sarmento Beires, he tries an unsuccessful direct
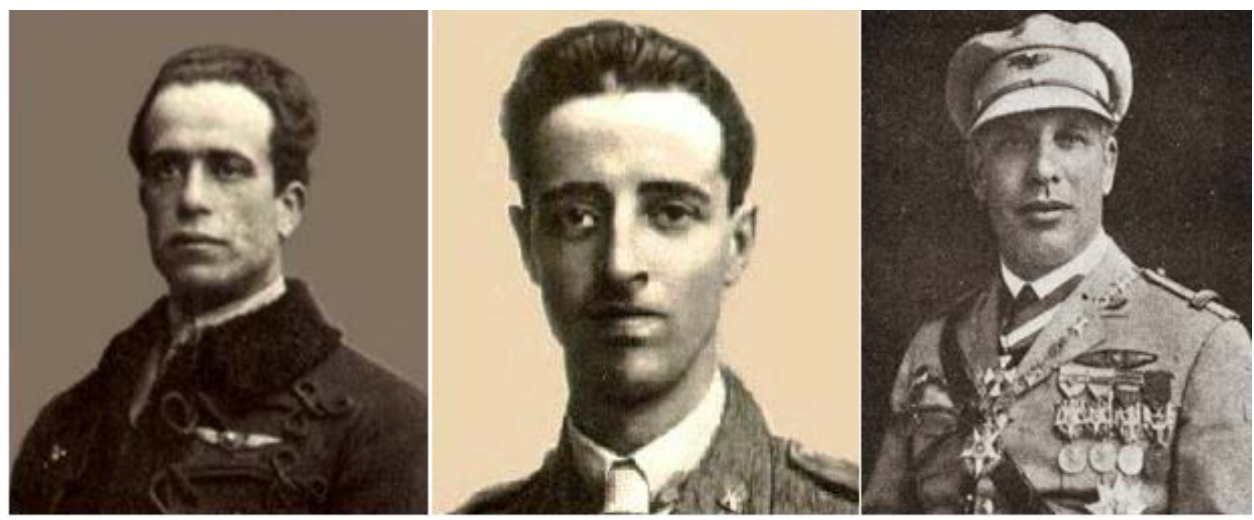

Figure 2. Portraits of the crew members: left) Brito Pais; center) Sarmento Beires, and right) Manuel Gouveia [2]. 
trip attempt to Madeira Islands aboard the airplane Breguet XIV A2, named "Cavaleiro Negro" [Black Knight] [2].

\subsection{Sarmento Beires}

José Manuel Sarmento Beires (Figure 2) (Lisbon, 04 September 1892-Oporto, 08 June 1974) became a Military College student and in 1916 he completes the course of Military Engineer in the School of War. In 1917 with the rank of Ensign, he completed successfully the first course of military pilot held at Portugal. In July 1917, he was promoted to the rank of Lieutenant and went to France, integrated at the Aviation Services of CEP.

At France he attended training courses, specializing in fighter aviation. In 1919 he returned to Portugal integrated in the Grupo de Esquadrilhas de Aviação República Squadrons Group of Republic Aviation. In 22 January 1920 Sarmento Beires became the first Portuguese pilot to perform a night flight mission. Also in 1920 along with Brito Pais, he tries an unsuccessful direct trip attempt to Madeira Islands aboard the airplane Breguet XIV A2, named "Cavaleiro Negro" [2].

\subsection{Manuel Gouveia}

Manuel António Gouveia (Figure 2) (Oporto, 04 February 1890-Lisbon, 10 December 1966). In 1912 became working at Companhia de Caminhos de Ferro, (Railways Company) at Cova da Moura, Lisbon. In 1917 he was mobilized for France where he joined the Portuguese Expeditionary Corps. Also at France, Captain Pilot Aviator Norberto Guimarães who led the Portuguese Aviation Military service, invited him to join the Portuguese Air Force. Manuel Gouveia attended both the Mechanical School of Saint Cyr and the Gnome-Rhône factories (Gnome-Rhône was a major French aicraft engine manufacturer predecessor of Snecma), working finally for the aircraft factory Hispano-Suiza in France (Hispano-Suiza was a Spanish automotive and engineering enterprise that in 1970 became a subsidiary of Snecma). Gouveia was also invited to be part of a team in order to acquire material in France, and thus to prepare a new aircraft unity Squadron at Amadora. He returned to Portugal in December 1919 and was appointed Chief Mechanic of the SPAD S.VII Squadron at Amadora. SPAD S.VII was a highly successful biplane fighter aircraft produced by Société Pour L'Aviation et ses Dérivés). Later he was invited by Brito Pais and Sarmento Beires to become part and to complete the crew in a voyage from Lisbon to Macau held in 1924 [2].

\section{Journey Part I; Onboard Crew: Brito Pais and Sarmento Beires}

The starting point of this trip was scheduled for the Amadora, further later changed to Vila Nova de Milfontes runway, due to its comparatively better conditions for a safety fully loaded take-off. On 2 April the airplane flew from Amadora to Vila Nova de Milfontes, a distance of nearly $130 \mathrm{~km}$ in 50 minutes. On 4 April, a day with intense downpours, the aircraft was completely fuel loaded and was effectively christened by the Beja Bishop with the name of "Pátria". Until 6 April the weather conditions worsened, preventing the pilots to initiate the Voyage. All presented distances along the 
following flight stages, were calculated by the pilots as a function of performed flight stages; as well, the average speed calculations were made according to pilots by removing 5 minutes corresponding to the time spent on runway turnarounds during departures and arrivals [1].

\subsection{1st Flight Stage: Vila Nova De Milfontes $\Rightarrow$ Málaga}

Finally on the 7 April at 6:02 h (departure timetable schedule along all flight stages were according to local time.), Brito Pais and Sarmento Beires onboard the "Pátria", took off from Vila Nova de Milfontes $\left(37^{\circ} 43^{\prime} \mathrm{N} 8^{\circ} 47^{\prime} \mathrm{W}\right)$ with a flight altitude leveled at 700 meters. Shortly after departure they flew over Odemira $\left(37^{\circ} 35^{\prime} \mathrm{N} 8^{\circ} 38^{\prime} \mathrm{W}\right)$ and later VilaReal de Santo António $\left(37^{\circ} 15^{\prime} \mathrm{N} 6^{\circ} 57^{\prime} \mathrm{W}\right)$, the last Portuguese location immediately before Spanish territory. When flying over Huelva city $\left(37^{\circ} 16^{\prime} \mathrm{N} 6^{\circ} 57^{\prime} \mathrm{W}\right)$ the pilots were forced to descend to a 50 meters altitude due to dense and thick fog above, annulling their visibility. Despite of a slight improvement invisibility this became surrounded by very intense rainfall; even so, Brito Pais managed to set a route over Sevilla $\left(37^{\circ} 23^{\prime} \mathrm{N}\right.$ $6^{\circ} 00^{\prime} \mathrm{W}$ ) at 30 meters of altitude. After Sevilla a new route was set out to Malaga in vain; weather conditions forced them to fly to south-southwest for nearly 30 minutes until sighting the Tarifa Island $\left(36^{\circ} 00^{\prime} \mathrm{N} 5^{\circ} 36^{\prime} \mathrm{W}\right)$. At this geographical point a new route was set out to Malaga traveling at $220 \mathrm{~km} / \mathrm{h}$ [1]. By flying over the Algeciras Bay $\left(36^{\circ} 08^{\prime} \mathrm{N}\right.$ $\left.5^{\circ} 24^{\prime} \mathrm{W}\right)$ at an altitude of 800 meters the aircraft became wrapped on a turbulence and suffered an adverse aerodynamic phenomenon, dipping vertically for a few seconds; and due to inertia the engine has a fuel lack. The pilot managed to regain the stabilized flight after declining 400 meters [1] [2]. The heavy rains would continue to wrap them until Malaga $\left(36^{\circ} 43^{\prime} \mathrm{N} 4^{\circ} 25^{\prime} \mathrm{W}\right)$ arrival at 10:22 h. Soon after landing, a team of French mechanics provided fuel and oil for the next stage flight. The pilots had flown the first stage of this trip with a $630 \mathrm{~km}$ distance in $4: 30 \mathrm{~h}$ with an average of $146 \mathrm{~km} / \mathrm{h} \mathrm{[1]}$. The British press recorded the beginning of this voyage and the Malaga aircraft arrival [16].

\subsection{2nd Flight Stage: Málaga $\Rightarrow$ Oran}

After receiving meteorological information of favorable weather, the second stage flight began on 9 April at 10:31 h. The initial stage flight was to cross the Mediterranean Sea. The airplane took off from Malaga bound for Melilla (Spanish autonomous city at Moroccan territory, $35^{\circ} 16^{\prime} \mathrm{N} 2^{\circ} 56^{\prime} \mathrm{W}$ ). Five minutes after departure the fuel pump crashed, causing a failure at the engine and at the propeller rotations. The fuel tank supplier was permuted and the failure was rectified [2]. At 11:30 h the airplane flew over the Alboran Island $\left(35^{\circ} 56^{\prime} 13^{\prime \prime} \mathrm{N} 3^{\circ} 02^{\prime} 07^{\prime \prime} \mathrm{W}\right)$ and at $11: 45 \mathrm{~h}$ the pilots began to sight the Cabo das Três Forcas $\left(35^{\circ} 26^{\prime} \mathrm{N} 2^{\circ} 59^{\prime} \mathrm{W}\right)$ on the African coast. Shortly later they flew over Melilla and at 13:16 h landed at Oran $\left(35^{\circ} 41^{\prime} \mathrm{N} 0^{\circ} 38^{\prime} \mathrm{W}\right)$ at the magnificent La Senia airfield. They had just performed a $450 \mathrm{~km}$ stage flight in 2:45 h with an average speed of 166 $\mathrm{km} / \mathrm{h}$, flying at 1,700 meters of altitude. Soon after landing the airplane was housed at a hangar [1]. 


\subsection{3rd Flight Stage: Oran $\Rightarrow$ Tunis}

On 12 April, at 07:12 h began a new stage flight from Oran bound for Tunis. With 1,000 liters of fuel onboard, a route was set towards the city of Miliana $\left(36^{\circ} 18^{\prime} \mathrm{N} 2^{\circ} 13^{\prime} \mathrm{E}\right)$. The over flown regions were mainly mountainous areas. The chosen route flew over the cities of Argel $\left(36^{\circ} 46^{\prime} \mathrm{N} 3^{\circ} 03^{\prime} \mathrm{E}\right)$, Dellys $\left(36^{\circ} 55^{\prime} \mathrm{N} 3^{\circ} 53^{\prime} \mathrm{E}\right)$ and Béjaïa (formerly known as Bougie, $36^{\circ} 45^{\prime} \mathrm{N} 5^{\circ} 03^{\prime} \mathrm{E}$ ). At 13:00 $\mathrm{h}$ the pilots sighted the first city at Tunisian territory: Tabarka $\left(36^{\circ} 57^{\prime} \mathrm{N} 8^{\circ} 45^{\prime} \mathrm{E}\right)$. Near this city the airplane flew over an iron mine which misgoverned their compass, leading to flight guidance by the African coast contours. At 14:02 $\mathrm{h}$ and after two turnarounds for city reconnaissance, they landed at Tunis $\left(36^{\circ} 50^{\prime} \mathrm{N} 10^{\circ} 05^{\prime} \mathrm{E}\right)$ airfield. Half an hour later Manuel Gouveia arrived at the airfield and joined Brito Pais and Sarmento Beires for the stage flights to come. In this stage 1,100 $\mathrm{km}$ were flown along $06: 50 \mathrm{~h}$ at an average speed of $164 \mathrm{~km} / \mathrm{h}$ with an average altitude of 2,200 meters [1].

\section{Journey Part II; Onboard Crew: Brito Pais, Sarmento Beires and Manuel Gouveia}

\subsection{4th Flight Stage: Tunis $\Rightarrow$ Tripoli}

On a torrid morning of 14 April at 09:03 $\mathrm{h}$ the airplane took off from Tunis, with its full crew onboard: Brito Pais, Sarmento Beires and Manuel Gouveia. This stage would be carried out over the desert. Shortly after departure the pilots experienced even higher temperatures. By crossing the mountainous region of Djebelbou Kournine $\left(36^{\circ} 40^{\prime} \mathrm{N}\right.$ $\left.10^{\circ} 22^{\prime} \mathrm{E}\right)$ they flew enveloped on strong turbulence and subsequently by sand whirlwinds. The route was set to flew over the cities of M'saken ( $\left.36^{\circ} 43^{\prime} \mathrm{N} 10^{\circ} 34^{\prime} \mathrm{E}\right)$, El Djem $\left(35^{\circ} 17^{\prime} \mathrm{N} 10^{\circ} 42^{\prime} \mathrm{E}\right)$, Sfax $\left(34^{\circ} 45^{\prime} \mathrm{N} 10^{\circ} 44^{\prime} \mathrm{E}\right)$ and Mahares $\left(34^{\circ} 32^{\prime} \mathrm{N} 10^{\circ} 30^{\prime} \mathrm{E}\right)$. By overflying Mahares a new route was set to the Djerba island $\left(33^{\circ} 52^{\prime} \mathrm{N} 10^{\circ} 44^{\prime} \mathrm{E}\right)$ and over the cities of Zarzis $\left(33^{\circ} 31^{\prime} \mathrm{N} 11^{\circ} 07^{\prime} \mathrm{E}\right)$ and Zuwarah $\left(32^{\circ} 56^{\prime} \mathrm{N} 12^{\circ} 05^{\prime} \mathrm{E}\right)$. At $15: 53 \mathrm{~h}$, pilots landed at Tripoli $\left(32^{\circ} 53^{\prime} \mathrm{N} 13^{\circ} 09^{\prime} \mathrm{E}\right)$. Throughout this stage a fairly warm wind blew intensively from south and slowed the flight: a wind that almost suffocated the pilots. The runway approach was hampered by an atmospheric layer very difficult to cross. This stage had been a very hard experience for the pilots who had suffered the first desert hostilities along $650 \mathrm{~km}$ in flight time of $06: 50 \mathrm{~h}$, at an average speed of $104 \mathrm{~km} / \mathrm{h}$. Soon after landing the airplane was housed at a hangar [1].

\subsection{5th Flight Stage: Tripoli $\Rightarrow$ Khoms (Al Khums)}

On 16 April at 07:58 h, a new stage flight was set from Tripoli bound for Benghazi. Shortly after departure the airplane was jolted by a massive desert wind named "Guib$1 i^{\prime \prime}$. At 10:30 h the pilots found that the average speed was only $100 \mathrm{~km} / \mathrm{h}$. It was not prudent to continue the voyage. Brito Pais decided to return to Tripoli but managed to land at Khoms city $\left(32^{\circ} 31^{\prime} \mathrm{N} 14^{\circ} 24^{\prime} \mathrm{E}\right)$ advancing merely $100 \mathrm{~km}$ on this stage, despite being flown $500 \mathrm{~km}$ along 4:00 h. Manuel Gouveia had at his disposal all the needed supplies for the airplane [1]. 


\subsection{6th Flight Stage: Khoms (Al Khums) $\Rightarrow$ Benghazi}

On 18 April at 07:32 $\mathrm{h}$ the crew began another stage from Khoms to Benghazi. They flew over the cities of Misrata $\left(32^{\circ} 23^{\prime} \mathrm{N} 15^{\circ} 05^{\prime} \mathrm{E}\right)$, Tawergha $\left(31^{\circ} 58^{\prime} \mathrm{N} 15^{\circ} 03^{\prime} \mathrm{E}\right)$ and Sirte $\left(31^{\circ} 12^{\prime} \mathrm{N} 16^{\circ} 35^{\prime} \mathrm{E}\right)$ at an altitude of 2,400 meters following the African coast contours. The wind was stifling and the suspended sand on the wind narrowly restricted the visibility and caused pain at the pilot's eyes. Their experience had already revealed that it was dangerous to descend due to heat rise, sand concentration rise and air rarefaction. The pilot in command at this stage, Sarmento Beires momentarily lost the horizontality notion. Brito Pais managed to regain the stabilization and control of the flight through an air bubble compass. The burning wind almost suffocated the pilots, who drank sips of water quite often. Slowly the landscape began to change and they flew over Ajdabiya city $\left(30^{\circ} 45^{\prime} \mathrm{N} 20^{\circ} 13^{\prime} \mathrm{E}\right)$. At $13: 50 \mathrm{~h}$ they landed at Benghazi $\left(32^{\circ} 05^{\prime} \mathrm{N} 20^{\circ} 03^{\prime} \mathrm{E}\right)$, fulfilling the $800 \mathrm{~km}$ of this stage flight in $06: 18 \mathrm{~h}$ at an average speed of $129 \mathrm{~km} / \mathrm{h}$. The crew experienced and recorded a curious phenomenon: the mobility of the horizon; so quickly the horizon line had a limited range with very high mountains as suddenly an endless plain. The suspended sand eluded the pilots in order to lose their horizontality notion: the airplane was sometimes sloping with dangerous angles without the pilot's perception [1].

\subsection{7th Flight Stage: Benghazi $\Rightarrow$ Cairo}

On 20 April at $06: 19 \mathrm{~h}$, the airplane took off from Benghazi bound for Cairo for a peaceful stage flight of 1,350 km along 9:15 h of flight time. After flying over Derna city $\left(32^{\circ} 46^{\prime} \mathrm{N} 22^{\circ} 38^{\prime} \mathrm{E}\right)$ the stage flight became monotonous. The followed route was again set by the contours of the African coast and flew over the cities of Tobruk $\left(32^{\circ} 04^{\prime} \mathrm{N}\right.$ $\left.23^{\circ} 57^{\prime} \mathrm{E}\right)$, Sidi Barrani $\left(31^{\circ} 56^{\prime} \mathrm{N} 25^{\circ} 55^{\prime} \mathrm{E}\right)$, Mersa Matruh $\left(31^{\circ} 21^{\prime} \mathrm{N} 27^{\circ} 14^{\prime} \mathrm{E}\right)$, El Dabaa $\left(31^{\circ} 02^{\prime} \mathrm{N} 28^{\circ} 26^{\prime} \mathrm{E}\right)$ and Tanta $\left(30^{\circ} 47^{\prime} \mathrm{N} 31^{\circ} 00^{\prime} \mathrm{E}\right)$. They landed at Cairo $\left(30^{\circ} 02^{\prime} \mathrm{N} 31^{\circ} 14^{\prime} \mathrm{E}\right)$ at 15:34 h. They had flown at an altitude of 2,500 meters with favorable weather and at an average speed of $148 \mathrm{~km} / \mathrm{h}$. At Cairo, the recorded temperature at shade was $46^{\circ} \mathrm{C}$. From Portugal to Cairo the airplane has flown approximately a total of 5,530 km [1]. The British press recorded the arrival of the Portuguese pilots at Cairo [17].

\subsection{8th Flight Stage: Cairo $\Rightarrow$ Riyaq}

On 23 April at $05: 35 \mathrm{~h}$ on take-off runway, after a 200 meters run, a tire broke violently; the pilot managed to cut engine contact and stopped the airplane safely, narrowly avoiding an accident. The situation became difficult because there were no spare tires. After a few minutes of bewilderment, Brito Pais decided to replace and use the tires of an old DeHavill and DH9 on sight at the runway. The tires were immediately handed over and Manuel Gouveia further raided by a mechanical team switched the tires. The departure from Cairo bound for Riyaq was at $06: 30 \mathrm{~h}$. The chosen route flew over the city of Zagazig $\left(31^{\circ} 30^{\prime} \mathrm{N} 30^{\circ} 34^{\prime} \mathrm{E}\right)$, Port Said $\left(31^{\circ} 14^{\prime} \mathrm{N} 32^{\circ} 17^{\prime} \mathrm{E}\right)$ and crossed the Suez Canal. The flight altitude was 200 meters due to clouds that whipped the airplane with heavy rains. Shortly after they left African territories behind them and flew over the 
cities of Gaza $\left(31^{\circ} 30^{\prime} \mathrm{N} 34^{\circ} 26^{\prime} \mathrm{E}\right)$ and Jaffa (the oldest southern part of Tel Aviv-Jaffa, $\left.32^{\circ} 03^{\prime} \mathrm{N} 34^{\circ} 45^{\prime} \mathrm{E}\right)$. Meantime the weather conditions became less unfavorable, allowing a route of 600 meters altitude flying over the cities of Haifa $\left(32^{\circ} 49^{\prime} \mathrm{N} 34^{\circ} 58^{\prime} \mathrm{E}\right)$, Acre $\left(32^{\circ} 55^{\prime} \mathrm{N} 35^{\circ} 04^{\prime} \mathrm{E}\right)$ and Beirut $\left(33^{\circ} 53^{\prime} \mathrm{N} 35^{\circ} 30^{\prime} \mathrm{E}\right)$ and turned to east to cross a $40 \mathrm{~km}$ mountainous terrains until Riyaq $\left(33^{\circ} 51^{\prime} \mathrm{N} 36^{\circ} 00^{\prime} \mathrm{E}\right)$. The route was rose to 2,200 meters and the mountains were crossed safely. When the pilots began the descent process the airplane was shaken by strong swirling winds. At 200 meters above the runway the frigid wind played with the airplane as if it were a paper rag. At 11:50 h they managed to land safely. Despite the $8^{\circ} \mathrm{C}$ the crew was completely flooded with sweat. Manuel Gouveia began an engine overhaul that lasted few hours, previously scheduled for this stopover. The $760 \mathrm{~km}$ of this stage had been flown in 5:10 h with an average speed of $149 \mathrm{~km} / \mathrm{h}$. On ground, Sarmento Beires drove the airplane to hangar's entrance where French Officers immediately congratulated the Portuguese crew and provided a mechanical team as well as fuel and oil at crew's disposals [1].

\subsection{9th Flight Stage: Riyaq $\Rightarrow$ Baghdad}

On 26 April at 08:05 $\mathrm{h}$ the crew began the stage from Rayak to Baghdad. During the first 30 minutes of flight the airplane described an ascending spiral until achieve the 2,800 meters, enough altitude to cross the Mountains east of Riyaq. Shortly after they flew over Damascus $\left(33^{\circ} 31^{\prime} \mathrm{N} 36^{\circ} 17^{\prime} \mathrm{E}\right)$, following a hostile and dull trip over the desert. Three hours after departure the crew crossed with three British aircrafts on route to Cairo. After $850 \mathrm{~km}$ in 6:00 h of flight time they landed at Baghdad $\left(32^{\circ} 20^{\prime} \mathrm{N} 44^{\circ} 21^{\prime} \mathrm{E}\right)$. Manuel Gouveia worked almost all night long to prepare the airplane for the next day [1]. The British press recorded the arrival of the pilots at Baghdad [18]. Figure 3 presents a map illustrating the route followed by the crew from Portugal to Baghdad.

\subsection{0th Flight Stage: Baghdad $\Rightarrow$ Bushehr (Bushire)}

On 27 April at 07:18 h, due to a failure at the engine ignition plugs after 18 minutes of

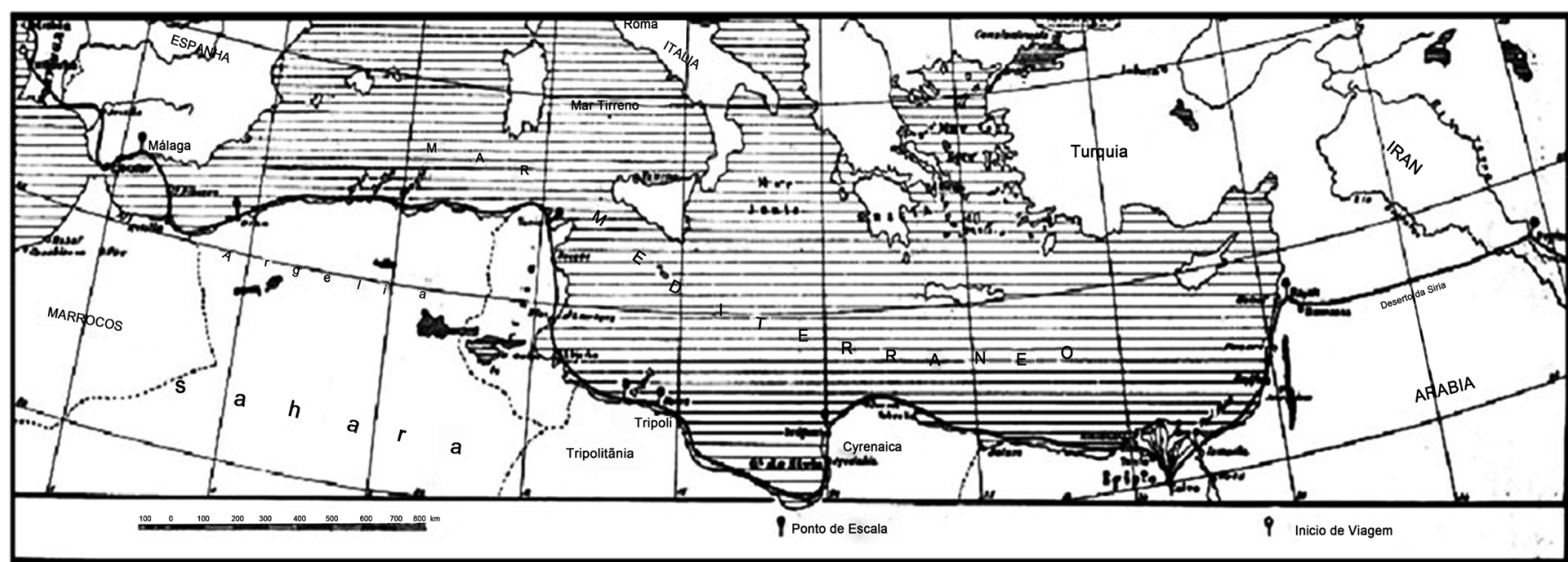

Figure 3. Route followed by the crew from Vila Nova de Milfontes to Baghdad [1]. 
flight, the pilots returned to Baghdad (flown distance of $40 \mathrm{~km}$ ). On 28 April the airplane flew from Baghdad to Bushire. The route of this stage was set between the courses of the Tigris and Euphrates rivers, which converge both at the Persian Gulf, right ahead the desired course. The followed route flew over the cities of Kut-el-Amara $\left(32^{\circ} 30^{\prime} \mathrm{N}\right.$ $\left.45^{\circ} 48^{\prime} \mathrm{E}\right)$, Amarah $\left(31^{\circ} 50^{\prime} \mathrm{N} 47^{\circ} 08^{\prime} \mathrm{E}\right)$ and Basra $\left(30^{\circ} 30^{\prime} \mathrm{N} 47^{\circ} 49^{\prime} \mathrm{E}\right)$. After Basra the airplane flew over a wet sand desert; by that time, the engine carburetion became poor and irregular and sometimes originated a decrease work regime. Shortly after the Persian Gulf cross at $12: 00 \mathrm{~h}$ the pilots sighted the city of Bushehr $\left(28^{\circ} 57^{\prime} \mathrm{N} 50^{\circ} 48^{\prime} \mathrm{E}\right)$ where they landed smoothly at 12:15 h. They had traveled $860 \mathrm{~km}$ in 6:05 h with an average of 143 $\mathrm{km} / \mathrm{h}$, cruising at an altitude of 900 meters. Manuel Gouveia conducted an inspection of the airplane's engine with the help of two French mechanics [1]. Along this flight stage the crew only had poor quality maps that indicated plains instead of swamps; cities instead of small villages and seaside regions of sand and silt instead of plains [2].

\subsection{1th Flight Stage: Bushehr (Bushire) $\Rightarrow$ Bandar Abbas}

After some diplomatic problems that had delayed their departure for a few days, on 2 May the pilots took off from Bushehr at 06:17 h and conducted a monotonous stage flight over the desert during $670 \mathrm{~km}$. The landscape was made up of very high mountains of gravel with deep ravines caused by rainwater. The weather was fantastic but the heat was stifling. At 10:48 $\mathrm{h}$ the pilots landed at Bandar Abbas $\left(27^{\circ} 10^{\prime} \mathrm{N} 56^{\circ} 16^{\prime} \mathrm{E}\right)$. This flight stage was completed in a flight time of $4: 31 \mathrm{~h}$ with an average speed of $149 \mathrm{~km} / \mathrm{h}$, with a maximum altitude of 1200 meters [1].

\subsection{2th Flight Stage: Bandar Abbas $\Rightarrow$ Chabahar}

On 3 May at 05:58 h the airplane took off from Bandar Abbas bound for Chabahar. The weather conditions were regular, despite of a scorching temperature. The stage flight was uneventful and the landscape was very similar to that observed throughout the previous stage. The route indicated the over flight of Bandar-e-Jask city $\left(25^{\circ} 38^{\prime} \mathrm{N} 57^{\circ} 46^{\prime} \mathrm{E}\right)$. At 09:28 h the pilots landed at Chabahar $\left(25^{\circ} 17^{\prime} \mathrm{N} 60^{\circ} 38^{\prime} \mathrm{E}\right)$. A flight time of 3:30 h had allowed them to make the $500 \mathrm{~km}$ of this stage at an altitude of 1600 meters.

By examining the airplane, it was found that the radiator was dripping water; however Chabahar lacked sufficient resources for this repair to be carried out and the engine continued to work perfectly. The crew will have to fly to another stopover to make the necessary repairs, revisions and maintenance of the aircraft [1] [2].

\subsection{3th Flight Stage: Chabahar $\Rightarrow$ Karachi}

On 4 May at 06:31 h the airplane took off from Chabahar bound for Karachi. The initial phase of this stage was flown at an altitude of 1,100 meters. Despite the early hour the heat was scorching. The airplane flew over Gwadar city $\left(25^{\circ} 07^{\prime} \mathrm{N} 62^{\circ} 19^{\prime} \mathrm{E}\right)$ and shortly after the pilots observed dense clouds on their route. These clouds began to obscure both land and sky and appeared to be composed by clay powder, sand and water vapor. At about 50 meters altitude pilots could sense the contours of the coast by the color of 
sea water; visibility was almost nil. The lower they flew, the higher was the temperature. From the coast side the sand clouds density was higher such as temperature. The engine managed to move the airplane following a completely irregular trajectory interspersed with altitudes of 10, 20 and 80 meters. Suddenly in front of the pilots appear the Hills of the Ormara Peninsula $\left(25^{\circ} 11^{\prime} \mathrm{N} 64^{\circ} 35^{\prime} \mathrm{E}\right)$, which they managed to avoid, but the aircraft was strongly shaken by a devastating windstorm till flew over the Sonmiani city $\left(25^{\circ} 25^{\prime} \mathrm{N} 66^{\circ} 35^{\prime} \mathrm{E}\right)$. Shortly after, the slight storm fading led to a flight altitude of 200 meters. By that time the engine issued four deafening crackles after returning to its normal working regime; flight was followed by a relative calm 20 minutes once again interrupted by new engine failure over the Hub river mouth $\left(24^{\circ} 53^{\prime} \mathrm{N} 66^{\circ} 41^{\prime} \mathrm{E}\right)$. The crew was determined for an emergency land in a slightly wavy terrain. In the terminal phase of the descent, the pilot forced an engine power contact and managed to avoid the emergency landing. The engine returned instantly to his normal rate regime. They resumed the route to fly the missing $50 \mathrm{~km}$ for Karachi. Meanwhile, the storm on their route took hellish proportions. Fortunately, the Manora port appeared at the horizon beside Karachi $\left(24^{\circ} 53^{\prime} \mathrm{N} 67^{\circ} 00^{\prime} \mathrm{E}\right)$. The storm perturbed the flight up to the runway but the pilots managed to land safely at 13:00 h. $880 \mathrm{~km}$ were flown in 6:29 h with very rough weather conditions. Hours later, the airplane was sheltered in a hangar and the engine was revised (Figure 4). The radiator repairs required a few hours of work. The pilots thought that the engine irregularity on the flight was due to deficiencies carburetion, an acceptable hypothesis due to the burning atmosphere [1]. Pilot's arrival to Karachi as well as the atmospheric conditions, in which the flight was conducted, were recorded by the British press [19].

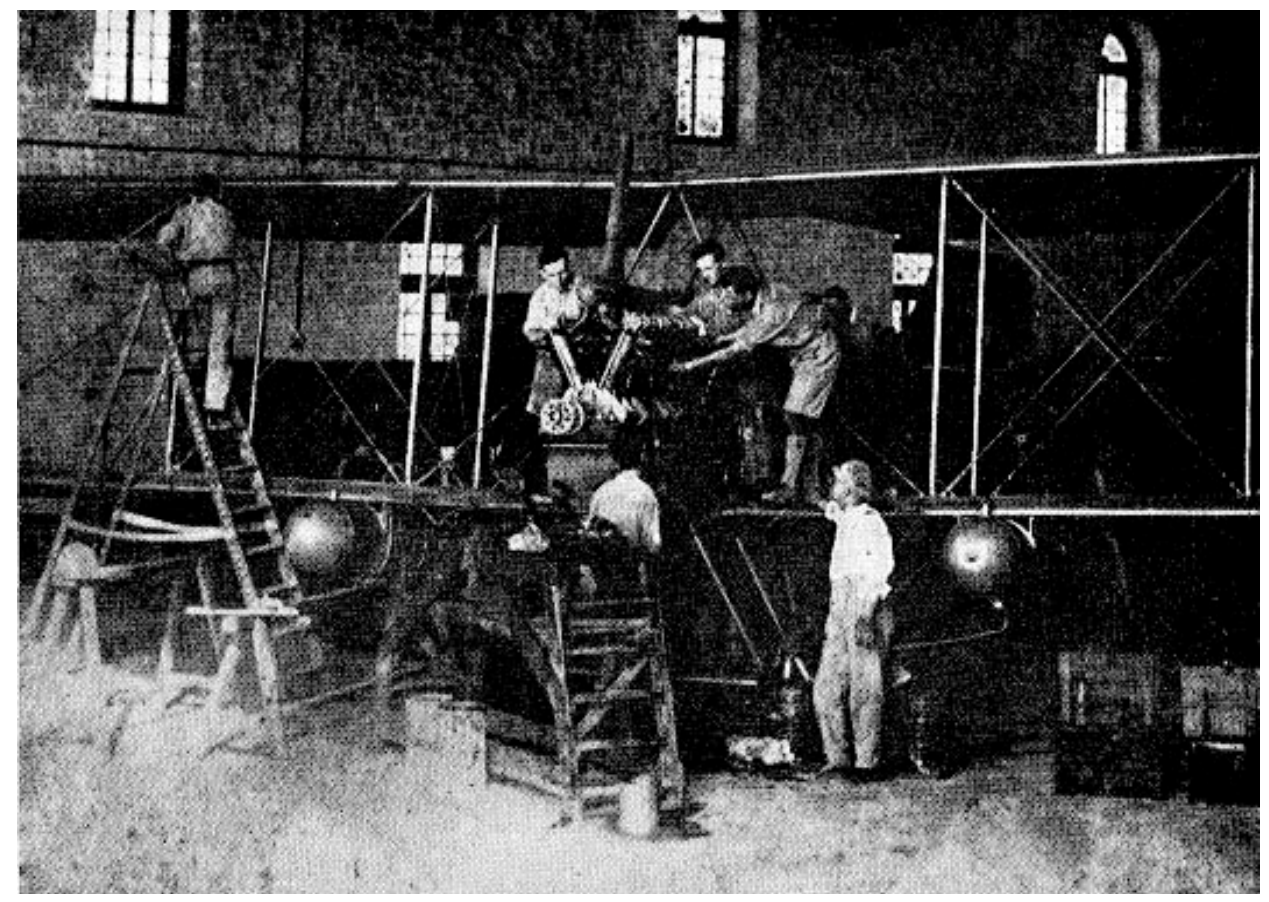

Figure 4. An engine inspection made at Drigh Road airfield hangar at Karachi [1]. 


\subsection{4th Flight Stage: Karachi $\Rightarrow$ Agra (Airplane Crash $10 \mathrm{Km}$ to Pipar Road)}

On 7 May at 06:18 h, began a new stage flight from Karachi bound for Agra. The first hours of flight were splendid. After passing Jodhpur city $\left(26^{\circ} 13^{\prime} \mathrm{N} 72^{\circ} 58^{\prime} \mathrm{E}\right)$ the atmosphere suddenly became a whirlwind, fierce and torrid, hampering the flight. The visibility became greatly reduced. The pilots tried in vain to ascend the altitude looking for fresher air. The engine was working at 1,500 rpm; however the airplane refused to obey and was losing altitude. The water temperature at the radiator was $90^{\circ} \mathrm{C}$. The crew had already exhausted all drinking water. The nearest airfield was over $100 \mathrm{~km}$. Later, at 10:35 $\mathrm{h}$ the airplane continued to lose altitude and was flying 300 meters above the ground. The pilot used the airplane's power engine to retard the altitude loss, however the landing was unavoidable. At that time the crew observed rectangular ground plains beside a village that could serve as a landing strip. When the airplane was about 2 meters from the ground a descendent wind gust projected the airplane on the ground; the apparatus lost a tire and was stuck by the sand, nearly capsizing. When the tail rose, the fuselage stringers break off altogether. The crew suffered minor bruises and managed to get off the airplane and the native population has provided them all the possible aids. The airplane crashed nearly $10 \mathrm{~km}$ of Pipar Road $\left(26^{\circ} 27^{\prime} \mathrm{N} 73^{\circ} 26^{\prime} \mathrm{E}\right)$, a village where the railroad could take the pilots by train to Jodhpur and subsequently to Karachi [1]. Table 1

Table 1. Resume of all flight stages onboard the airplane Breguet XIV Bn2 "Pátria" along the First Aerial Journey from Portugal to Macau, with total flight times and flown distance values presented for each flight stage.

\begin{tabular}{|c|c|c|c|c|}
\hline \multicolumn{5}{|c|}{ Airplane: Breguet XIV Bn2-“Pátria” } \\
\hline $\begin{array}{l}\text { Year } \\
1924 \\
\end{array}$ & Flight Stages & $\begin{array}{c}\text { Crew } \\
\text { onboard }\end{array}$ & $\begin{array}{l}\text { Flight Time } \\
\text { (h:m) }\end{array}$ & $\begin{array}{l}\text { Flown Distance } \\
(\mathrm{nm})\end{array}$ \\
\hline 7 April & Vila Nova de Milfontes $\Rightarrow$ Malaga & 2 & $4: 30$ & 630 \\
\hline 9 April & Malaga $\Rightarrow$ Oran & 2 & $2: 45$ & 450 \\
\hline 12 April & Oran $\Rightarrow$ Tunis & 2 & $6: 50$ & 1,100 \\
\hline 14 April & Tunis $\Rightarrow$ Tripoli & 3 & $6: 50$ & 700 \\
\hline 16 April & Tripoli $\Rightarrow$ Khoms & 3 & 4:00 & 500 \\
\hline 18 April & Khoms $\Rightarrow$ Benghazi & 3 & $6: 18$ & 800 \\
\hline 20 April & Benghazi $\Rightarrow$ Cairo & 3 & $9: 15$ & 1,350 \\
\hline 23 April & Cairo $\Rightarrow$ Riyaq & 3 & $5: 10$ & 760 \\
\hline 26 April & Riyaq $\Rightarrow$ Baghdad & 3 & 6:00 & 850 \\
\hline 28 April & Baghdad $\Rightarrow$ Bushehr & 3 & $6: 23$ & 900 \\
\hline 2 May & Bushehr $\Rightarrow$ Bandar Abbas & 3 & $4: 31$ & 670 \\
\hline 3 May & Bandar Abbas $\Rightarrow$ Chabahar & 3 & 3:50 & 550 \\
\hline 4 May & Chabahar $\Rightarrow$ Karachi & 3 & $6: 29$ & 880 \\
\hline \multirow[t]{2}{*}{7 May } & Karachi $\Rightarrow$ Agra (crash near Pipar Road) & 3 & $5: 20$ & 820 \\
\hline & & & $77: 11$ & 10,960 \\
\hline
\end{tabular}


presents a resume all flight stages onboard the airplane Breguet XIV Bn2 "Pátria" along the First Aerial Journey from Portugal to Macau, with total flight times and flown distance values presented for each flight stage. On this table, on the values presented at flight stage from Baghdad to Bushehr are related to the flight time of 18 minutes and a flown distance of $40 \mathrm{~km}$ performed on 27 April, plus the flight time of 6:05 h and a flown distance of $860 \mathrm{~km}$ performed on 28 April.

\section{Portuguese Government Acquires a New Aircraft}

Along 21 days the pilots negotiated with the Indian Government the purchase of a new apparatus in order to pursuit their voyage. On 20 May the Portuguese Consul of Bombay athwart the Portuguese Government finally managed to obtain a new airplane by 4,700 British pounds: a De Havill and DH9, 1920 model. This aircraft was equipped with a $400 \mathrm{hp}$ Liberty engine. It was agreed by the Portuguese Government and the De Havilland enterprise that the new airplane would be assembled at Lahore; Brito Pais and Manuel Gouveia would also attend total time assemblage. For this reason, the Journey should be restarted form Lahore. The crew agreed to keep the name of the airplane "Pátria IP" (Figure 5). Meanwhile on 18 May the wreckage of the "Pátria" went to Karachi and was removed to the Drigh Road airfield to be conveniently boxed and sent to Lisbon. The Renault 12 FE engine belonging to the airplane "Pátria" is to day exhibited at the Air Museumat Sintra-Lisbon. On 29 May the "Pátria IP" flew for the first time under the command of the English aviator, Lieutenant Oliver. Sarmento Beires was onboard that flight. During that morning they flew about 50 minutes around the runway: they performed three landings and reached the maximum altitude of 1,500 meters. During the afternoon they took off three times and flew only 10 minutes with Manuel Gouveia as a passenger. Due to the transport a few spare parts on this new aircraft, the complete crew consisted again in two persons: Commander and observer: Brito Pais; Pilot: Sarmento Beires. Manuel Gouveia would follow the route (by train) and would provide his mechanical services at stopovers without mechanical resources [1]. The information about the airplane crash and the acquisition of a second plane to continuing the Portuguese voyage was recorded by the British press [20].

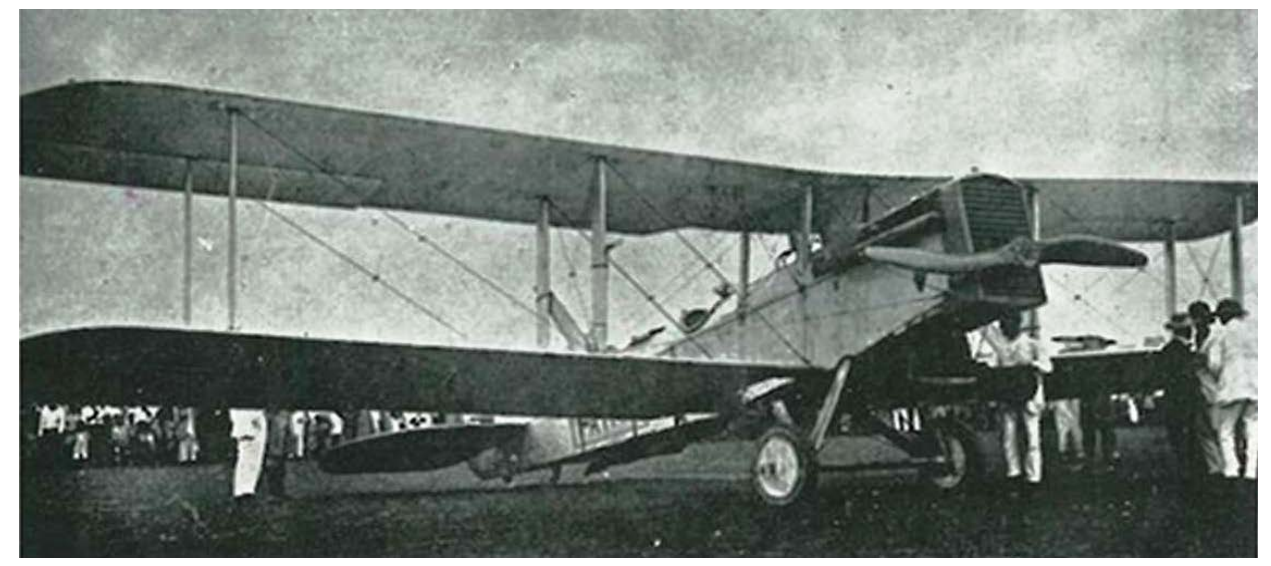

Figure 5. Photo of the airplane "Pátria IP” [2]. 


\section{Journey Part III; the New Aircraft De Havilland DH9 "Pátria II"}

\subsection{5th Flight Stage: Lahore $\Rightarrow$ Ambala}

On 30 May at $06: 15 \mathrm{~h}$, the "Pátria IP" took off from the Lahore runway (capital of the Pakistani province of Punjab, $\left.31^{\circ} 32^{\prime} \mathrm{N} 74^{\circ} 20^{\prime} \mathrm{E}\right)$ bound for Ambala $\left(30^{\circ} 22^{\prime} \mathrm{N} 76^{\circ} 46^{\prime} \mathrm{E}\right.$ ). The $290 \mathrm{~km}$ of this stage were carried out under a scorching heat; however, the flight was accomplished fairly quiet. With 2:05 $\mathrm{h}$ of time flown the pilots landed safely at Ambala. The airplane was parked at a hangar and was revised by an English mechani$\mathrm{cal}$, in order to continue the voyage in the next morning. Manuel Gouveia travelled by train to Ambala. During the train stop he spoke with Sarmento Beires and Brito Pais. Mean while Gouveia would follow by train to Allahabad, where its presence as essential; a stopover devoid of mechanical resources [1].

\subsection{6th Flight Stage: Ambala $\Rightarrow$ Allahabad (Prayag)}

On 31 May the aircraft took off from the Ambala runway bound for Allahabad. The weather was fine and visibility was excellent. The followed route flew over Lucknow $\left(26^{\circ} 50^{\prime} \mathrm{N} 80^{\circ} 56^{\prime} \mathrm{E}\right)$. The pilots sighted from a long distance the city of Kanpur and flew over Raebareli $\left(26^{\circ} 13^{\prime} \mathrm{N} 81^{\circ} 14^{\prime} \mathrm{E}\right)$. After $4: 30 \mathrm{~h}$ of flight time they landed at Allahabad $\left(25^{\circ} 26^{\prime} \mathrm{N} 81^{\circ} 50^{\prime} \mathrm{E}\right)$. They had flown $800 \mathrm{~km}$ at an average speed of $177 \mathrm{~km} / \mathrm{h}$ at maximum altitude of 2,200 meters. The temperature at Allahabad was $45^{\circ} \mathrm{C}$. That day Manuel Gouveia conducted an airplane thorough overhaul [1].

\subsection{7th Flight Stage: Allahabad (Prayag) $\Rightarrow$ Kolkata}

On 1 June Brito Pais and Sarmento Beires, took off the "Pátria IP" from Allahabad bound for Kolkata. The weather was rough, windy. They flew over Benares city (also known as Varanasi, $25^{\circ} 18^{\prime} \mathrm{N} 82^{\circ} 58^{\prime} \mathrm{E}$ ). This route was carried out at 2,200 meters altitude and passing near the Parasnath Hill $\left(23^{\circ} 57^{\prime} \mathrm{N} 86^{\circ} 08^{\prime} \mathrm{E}\right)$. When making a descent to Kolkata $\left(22^{\circ} 33^{\prime} \mathrm{N} 88^{\circ} 21^{\prime} \mathrm{E}\right)$, the crew had to face once more the maelstrom of a torrid atmosphere. They landed safely, however at the runway they had to avoid a herd of cows. The airplanes of that time had no brakes. The local temperature was $42^{\circ} \mathrm{C}$ in the shade. They flew the $800 \mathrm{~km}$ in just 4:15 hat an average speed of $195 \mathrm{~km} / \mathrm{h}$. On the runway, some personalities were to waiting to receive them: The Consul of Portugal, the Consul of Brazil, some British officers and a Reverend. Mean while Gouveia arrived at Kolkata. The pilots were forced to stay three days in this city, to satisfy those who wished to render homage to them [1]. The British press recorded the arrival of the pilots to Kolkata [21].

\subsection{8th Flight Stage: Kolkata $\Rightarrow$ Akyab}

On 4 June the crew hailed the personalities and Manuel Gouveia and began the stage flight Kolkata-Akyab (actually known as Sittwe, Myanmar). The pilots flew over the Ganges river mouth and later flew over the city of Chittagong $\left(22^{\circ} 19^{\prime} \mathrm{N} 91^{\circ} 46^{\prime} \mathrm{E}\right)$. The airplane flew wrapped by downpours and by southwest wind that slowed the flight. The 
followed route was over the coast line contours. Finally they landed at Akyab $\left(20^{\circ} 08^{\prime} \mathrm{N}\right.$ $92^{\circ} 52^{\prime} \mathrm{E}$ ). They flew $650 \mathrm{~km}$ in 3:55 hat an average speed of $162 \mathrm{~km} / \mathrm{h}$ on a route carried out at 2,200 meters altitude. The first person to approach the airplane at the runway was Panderleith, the pilot who accompanied Capt. McLaren [1] in his British Attempt of Aerial Circumnavigation.

\subsection{9th Flight Stage: Akyab $\Rightarrow$ Rangoon}

On 5 June the aircraft took off in a morning of poor weather conditions: thunderstorm with strong winds. The pilots flew 1:55 h performing a flight distance of $260 \mathrm{~km}$; however they were unable to cross the dense fog and returned back to Akyab. On 6 June at 09:10 $\mathrm{h}$, the airplane took off from Akyab toward Rangoon. The atmospheric conditions allowed the pilots following a route with an altitude of 4000 meters flying over the Arakan Mountains. After flying over the city of Hinthada (formerly Henzada, $17^{\circ} 39^{\prime} \mathrm{N}$ $95^{\circ} 27^{\prime} \mathrm{E}$ ) they descended to 1,000 meters altitude to avoid the wind bustle. When flying over the city of Rangoon $\left(16^{\circ} 49^{\prime} \mathrm{N} 96^{\circ} 08^{\prime} \mathrm{E}\right)$ the pilots observed cross winds over the runway, which was in fact a field of horse racing. At 13:15 h they landed safely at the third attempt, after escaping from at angle of telephone wires. The pilots were exhausted due to time travel to 4,000 meters altitude. At this stage the pilots accomplished the $650 \mathrm{~km}$ flight in 4:05 h [1].

\subsection{0th Flight Stage: Rangoon $\Rightarrow$ Bangkok}

On 9 June at $08: 40 \mathrm{~h}$ the pilots conducted a leveraging take-off in about 300 meters of the runway total length. After take-off they took the route to Bangkok. About $40 \mathrm{~km}$ east of Rangoon they began to fly over the sea (Martaban Golf) for about 15 minutes, followed by the flew over of Mawlamyne city $\left(16^{\circ} 28^{\prime} \mathrm{N} 97^{\circ} 37^{\prime} \mathrm{E}\right)$. The sky was clear and the pilots decided to ascend to a route of 4,500 meters. The scheduled route flew over the Ayutthaya city $\left(14^{\circ} 21^{\prime} \mathrm{N} 100^{\circ} 35^{\prime} \mathrm{E}\right)$. The landing at Bangkok $\left(13^{\circ} 46^{\prime} \mathrm{N} 100^{\circ} 30^{\prime} \mathrm{E}\right)$ proceeded smoothly at 13:55 h. The runway was magnificent. The duration of the 680 $\mathrm{km}$ of this stage was 5:15 h with an average speed of $129 \mathrm{~km} / \mathrm{h}$. Despite this average speed the pilots considered as a restful stage. The aircraft had a team of mechanics waiting for his arrival and all the needed fuel. It was necessary to replace a depth tiller cable, as well as cobble the skin fuselage. The crew had some individualities waiting for them, as usual [1].

\subsection{1st Flight Stage: Bangkok $\Rightarrow$ Ubon Ratchathani}

On 11 June the weather had drizzle, clouds and wind. Despite such circumstances at 07:05 $\mathrm{h}$ the airplane took off from Bangkok bound for Ubon Ratchathani city. The pilots took the route to the Korat city (also known as Nakhon Ratchasima, $14^{\circ} 58^{\prime} \mathrm{N}$ $\left.102^{\circ} 06^{\prime} \mathrm{E}\right)$. This city offered an airfield resource. Despite the rain and wind, this stage flight took place normally. The aircraft landed at Ubon Ratchathani $\left(15^{\circ} 14^{\prime} \mathrm{N} 104^{\circ} 50^{\prime} \mathrm{E}\right)$ at 10:10 h. They had flown $550 \mathrm{~km}$ in 3:05 h at a maximum altitude of 600 meters. Their average speed recorded was $177 \mathrm{~km} / \mathrm{h}$. The airplane was gathered at a hangar for washing 
and cleaning; later the airplane was prepared for the next stage flight [1].

\subsection{2nd Flight Stage: Ubon Ratchathani $\Rightarrow$ Hanoi}

On 12 June at 06:55 h, surrounded by downpours the airplane took off from Ubon Ratchathani bound for Hanoi. Until Takhèk city $\left(17^{\circ} 24^{\prime} \mathrm{N} 104^{\circ} 50^{\prime} \mathrm{E}\right)$ the flight was over a blanket of clouds with almost null ground visibility. The navigation altitude was 2,500 meters, enough to overcome the mountainous region along their route. For about an hour they navigated completely blind by flying over the mountains just seeing the clouds covering them. They sighted the China Sea from afar and later flew over the HàTinh city $\left(18^{\circ} 20^{\prime} \mathrm{N} 105^{\circ} 54^{\prime} \mathrm{E}\right)$. In the meantime the airplane's engine began shuddering with sudden glitches that disquieted the crew completely. The nearest runway at Vinh city $\left(18^{\circ} 40^{\prime} \mathrm{N} 105^{\circ} 41^{\prime} \mathrm{E}\right)$ was nearly $100 \mathrm{~km}$ behind their actual position and the crew decided not turn back, considering a stopover at Nam Định city $\left(20^{\circ} 24^{\prime} \mathrm{N} 106^{\circ} 10^{\prime} \mathrm{E}\right)$ if necessary; by flying over that city they decided to continue the flight. Later on, they sighted the Red river and the Haiphong city $\left(20^{\circ} 50^{\prime} \mathrm{N} 106^{\circ} 40^{\prime} \mathrm{E}\right)$. Compact clouds suddenly come to light along their route forcing the pilots to descend the aircraft altitude; from 1,800 to just 20 meters above the ground, the highest altitude which enabled pilots to regain their horizon and visibility. The last $100 \mathrm{~km}$ of this stage were flown at a 20 meters altitude forcing the pilot to a very hard work. At 12:00 $\mathrm{h}$ the translucency of the atmosphere transpired the city of Hanoi. The pilots spent some time searching the airfield, which they recognized by the hangars and by the high radio communications masts. After a turnaround they observed that the runway was completely flooded, notwithstanding they had to land. At 12:45 h the aircraft landed managing to avoid overturning and was safely immobilized, later taken to a hangar. $780 \mathrm{~km}$ of a very stressful flight had been performed in 5:50 h at an average speed of $136 \mathrm{~km} / \mathrm{h}$. The British press recorded that day the following news: "While at Rangoon they received a message from the Portuguese Government promoting Brito Pais and Sarmento Beires to the rank of Major and also receiving the Order of the Tower and Sword. Their Mechanic Manuel Gouveia was also promoted to the rank of Lieutenant' [22]. The following days at Hanoi were quite rainy, and gradually transformed the runway contours into a quagmire, presenting nearly $20 \mathrm{~cm}$ of water above the soil; it was not prudent to take-off [2].

\subsection{3rd Flight Stage: Hanoi $\Rightarrow$ Tông}

By the appointment of Lieutenant Roger Guillaumot, the crew inspected a reciprocating airfield at Tông location $\left(21^{\circ} 06^{\prime} \mathrm{N} 105^{\circ} 29^{\prime} \mathrm{E}\right)$ nearly $40 \mathrm{~km}$ from Hanoi. On 17 June the runway portion with consistent soil was about a 100 by 20 meters strip. The aircraft was lightened of all unnecessary loads and due to bad weather conditions and a very poor runway, the "Pátria IP" was transferred to Tông airfield in a flight of $100 \mathrm{~km}$ and 45 minutes. During this flight the engine had a failure, yet the aircraft landed normally. The local mechanic made an engine overhaul but unfortunately the failure persisted. The crew decided to wait for Manuel Gouveia arrival. Nevertheless on the afternoon of 19 June when conducted new engine tests the failure had disappeared and the engine 
worked in perfection [1].

\subsection{4th Flight Stage: Hanoi $\Rightarrow$ Macau (Airplane Crash Near Fanling after Over Flown Macau)}

On 20 June at 09:58 h, the airplane took off from Tông with clear skies, ready to accomplish the last $1,000 \mathrm{~km}$ to Macau. The velocimeter was disabled but the engine was working in perfection. The route was set to fly over Haiphong and Beihai $\left(21^{\circ} 28^{\prime} \mathrm{N}\right.$ $\left.109^{\circ} 06^{\prime} \mathrm{E}\right)$. By flying over the French domination region known as Kouang-TcheouWang $\left(21^{\circ} 27^{\prime} \mathrm{N} 110^{\circ} 38^{\prime} \mathrm{E}\right)$ their visibility reduced slightly but the flight progressed fast and normal. At 13:00 $\mathrm{h}$ they sighted the city of Yangjiang $\left(21^{\circ} 51^{\prime} \mathrm{N} 111^{\circ} 58^{\prime} \mathrm{E}\right)$. Gradually storms began to grown and thicken; a few minutes later they became surrounded by thunderstorms and lightnings and thick ropes of oblique water. They lacked $150 \mathrm{~km}$ to Macau. The wind began to blow mighty strong. If they receded, the nearest airfield was $200 \mathrm{~km}$ behind. The crew decided to rose for a 2,800 meters altitude in a desperate attempt to overcome the storm, in vain because the flight became even more tragic, with almost continuous lightning. Suddenly the engine hesitated slightly and the voltmeter's indicator announced a disabled power generator. The crew knew theoretically that they could manage to fly about two hours with the battery charge and that under normal circumstances they would take nearly 30 minutes to reach Macau. The airplane flew at high speed and nearly 20 minutes later Brito Pais discerned a known location: the Lapa Island beside Macau $\left(22^{\circ} 12^{\prime} \mathrm{N} 113^{\circ} 32^{\prime} \mathrm{E}\right)$. At $14.30 \mathrm{~h}$ they flew over Macau under a scourge of dense and furious downpours that seemed insurmountable. The pilots attempted to describe a circle over Macau but the whirlwind has widened that circle too much. To retry their way back to Macau, on route was again a liquid barrier, opaque and black. The situation worsened. They tried again an approximation to Macau but the wind was whipping the airplane that flew about 10 meters above the sea. The lightning had ceased but the rain continued extremely vigorous. The engine started to lower its work regime and vibrating alarmingly. The aircraft was in danger. Brito Pais and Sarmento Beires observed a lightly concave place to try to land. On landing the airplane's wheels hit a small slope and broke the propeller and landing gear (Figure 6). The voyage was over. The "Pátria IP" flew over Macau after completing the route Portugal-India. Figure 7 illustrates the route followed by the airmen onboard the "Pátria $I P^{\prime}$. On this final flight stage, navigators flew $1,050 \mathrm{~km}$ over $4: 50 \mathrm{~h}$ at an average speed of $217 \mathrm{~km} / \mathrm{h}$. In the last hour they had flown $262 \mathrm{~km}$. The airplane crashed on Chinese territory, very near the town of Fanling (British territory at Hong Kong, $22^{\circ} 30^{\prime} \mathrm{N}$ $\left.114^{\circ} 08^{\prime} \mathrm{E}\right)$. After crash the crew walked on foot until reach the China-Hong Kong border and then traveled by train from Fanling to the port city of Kowloon $\left(22^{\circ} 18^{\prime} \mathrm{N}\right.$ $\left.114^{\circ} 10^{\prime} \mathrm{E}\right)$. On 26 June 1924, the British press recorded the crash land of Portuguese crew after flown over Macau [23]. So, thus ended the Journey que became known to the First Aerial Journey from Portugal to Macau, a journey performed as inspiration for a future Portuguese around the World Flight attempt. The Portuguese Aeronautics rejoiced auspicious days that time; after Coutinho and Cabral great achievement on 1922, with the First Flight from Europe to the South Atlantic, Portuguese aviation pioneers once 

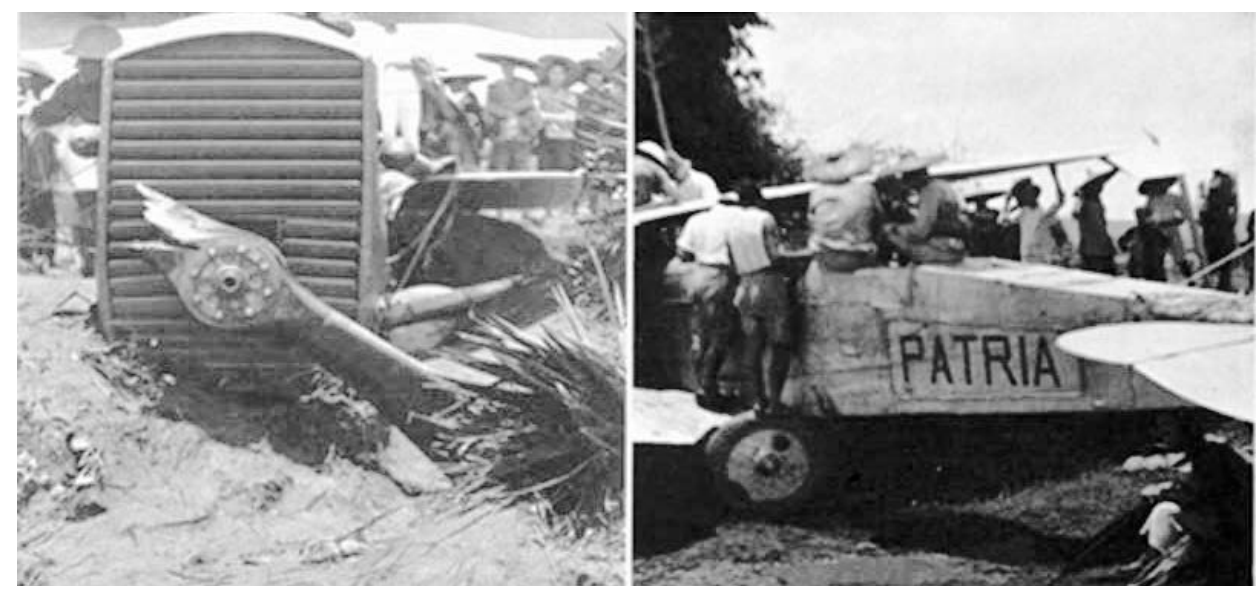

Figure 6. Photos of the "Pátria IP" crash landing at China [1].

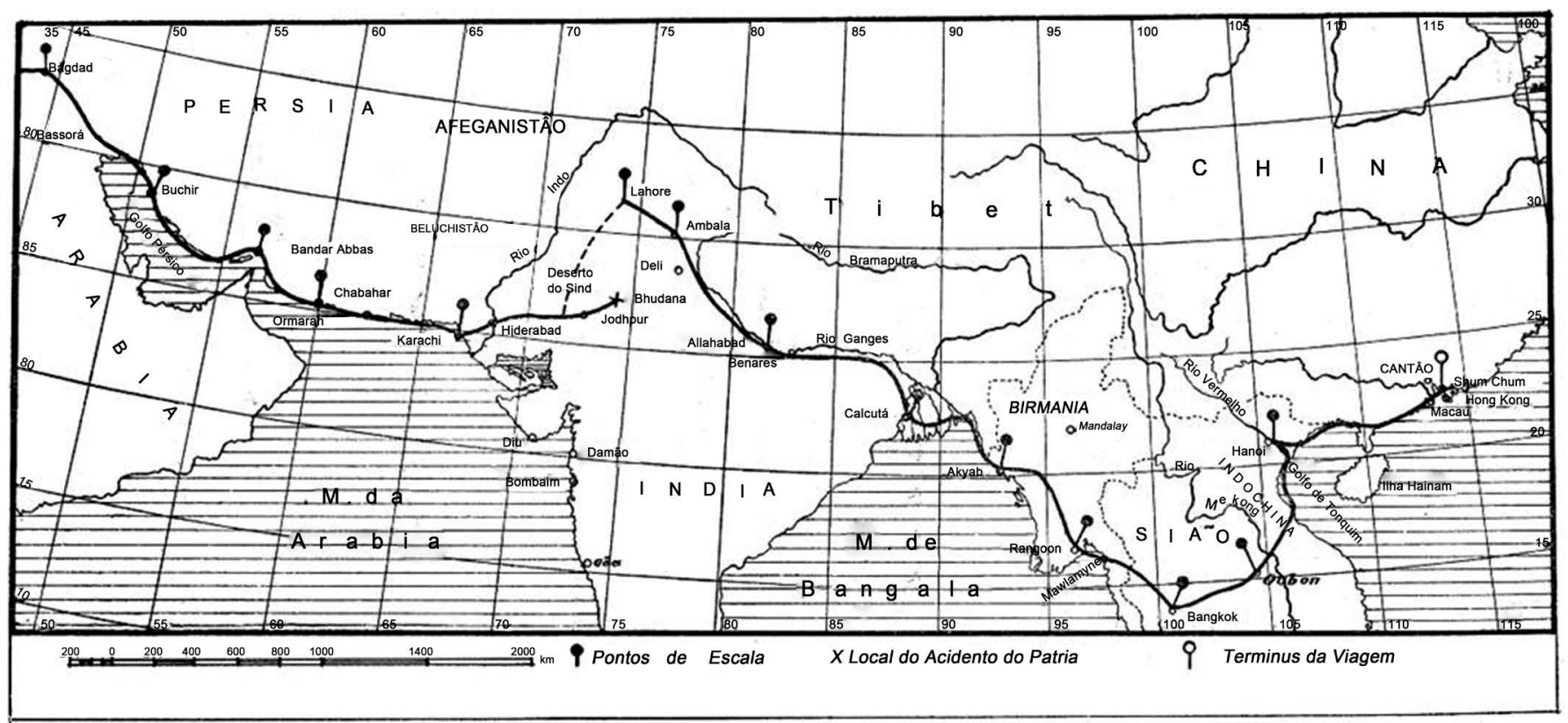

Figure 7. Route followed by the crew from Lahore to Macau [1].

again performed another intercontinental flights, practically an half aerial Circumnavigation flight. Figure 8 illustrates a Portuguese Government tribute to Sarmento Beires, Brito Pais and Manuel Gouveia, for the merit and prestige contribution to the Portuguese Aviation by performing the First Aerial Journey from Portugal to Macau. Table 2 presents a resume of all flight stages onboard the airplane De Havilland DH9-Pátria II along the same Journey, with total flight times and flown distance values presented for each flight stage. On this table, on the values presented at flight stage from Akyab to Rangoon are related to the flight time of $1: 55 \mathrm{~h}$ and a flown distance of $260 \mathrm{~km}$ performed on 5 June, plus the flight time of $4: 05 \mathrm{~h}$ and a flown distance of $650 \mathrm{~km}$ performed on 6 June.

Also on 20 June hours after the accident and after having revisited with the competent 


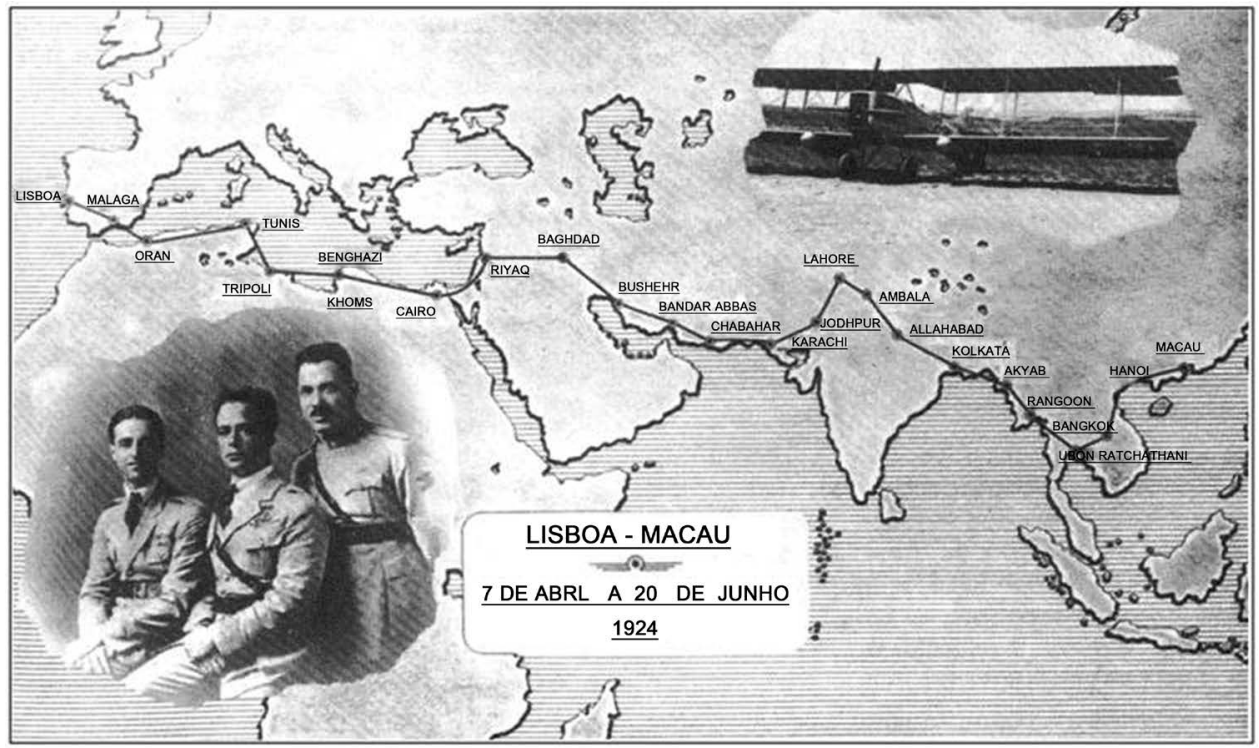

Figure 8. Portuguese government tribute to Sarmento Beires, Brito Pais and Manuel Gouveia, for the merit and prestige contribution to the Portuguese aviation by performing the first aerial journey from Portugal to Macau [2].

Table 2. Resume of all flight stages onboard the airplane De Havilland "Pátria IP" along the first aerial journey from portugal to macau, with total flight times and flown distance values presented for each flight stage.

\begin{tabular}{ccccc}
\hline \multicolumn{5}{c}{ Airplane: De Havilland DH9-“Pátria IP” } \\
\hline Year 1924 & Flight Stages & Crew onboard & $\begin{array}{c}\text { Flight Time } \\
(\mathrm{h}: \mathrm{m})\end{array}$ & $\begin{array}{c}\text { Flown } \\
\text { Distance (nm) }\end{array}$ \\
\hline 30 May & Lahore $\Rightarrow$ Ambala & 2 & $2: 05$ & 290 \\
31 May & Ambala $\Rightarrow$ Allahabad (Prayag) & 2 & $4: 30$ & 800 \\
1 June & Allahabad (Prayag) $\Rightarrow$ Kolkata & 2 & $4: 15$ & 800 \\
4 June & Kolkata $\Rightarrow$ Akyab & 2 & $3: 55$ & 650 \\
6 June & Akyab $\Rightarrow$ Rangoon & 2 & $6: 00$ & 910 \\
9 June & Rangoon $\Rightarrow$ Bangkok & 2 & $5: 15$ & 680 \\
11 June & Bangkok $\Rightarrow$ Ubon Ratchathani & 2 & $3: 05$ & 550 \\
12 June & Ubon Ratchathani $\Rightarrow$ Hanoi & 2 & $5: 50$ & 780 \\
17 June & Hanoi $\Rightarrow$ Tông & 2 & $0: 45$ & 100 \\
20 June & Tông $\Rightarrow$ Macau (crash near Fanling) & 2 & $4: 50$ & 1050 \\
& & & $40: 30$ & 6610 \\
\hline
\end{tabular}

authorities the airplane crashed, the crew was received by the Portuguese colony of Hong Kong with the presence of the Portugal Consul. The following days were intended for the airplane disassembles. Manuel Gouveia arrived at Hong Kong on 24 June. On 25 June the pilots boarded the gunboat also named "Pátria" and at 15:30 h they were disembarking at Macau. The following days were nonstop party.

\section{Commemorations and Tributes}

By order of His Excellency the Governor of Macau, Dr. Rodrigo Rodrigues, the team of 
the airplane "Pátria" would return to Portugal, via North America, visiting the Portugueses nuclei at Shanghai, Tokyo and some cities in the United States. In American territory, the pilots visited Vancouver, Seattle, San Francisco, Oakland, San Jose, Sacramento, Boston (Figure 9), New Bedford, Providence, Fall River, New York, Newark and Jersey City. On 28 August the pilots embarked for Europe aboard the ship Aquitania. On the night of 2 September they arrived to London. On 7 September the ship Arlanza with pilots on board, heads from Southampton to Lisbon, arriving that city at noon of 9 September [1]. On 14 September the Portuguese people came out to the street to acclaim their heroes.

Some parts of the damaged "Pátria IP' remained today at Clube Lusitano de Hong Kong (Hong Kong Lusitanian Club). Written down at a book edited by the pilot Sarmento Beires [1], flight times and flown distances on this Voyage, for each airplane were the following: "Pátria": Total Route Flown: 10,960 km; Total Time Flown: 77:11 h; "Pátria IP": Total Route Flown: 6610 km; Total Time Flown: 40:30 h. The pilots flew a total of approximately 16,760 kilometers in 117:41 h, facing often extremely adverse atmospheric conditions, sandstorms and inaccurate navigation maps. The Portuguese Government issued postage stamps commemorating this Voyage. The Portaria [Ministerial Order] No.90/99/ M from Macau dating back to 29 March 1999 has authorized special stamps broadcast entitled "75 Anos da Primeira Ligação Aérea Portugal Macau" $-\left[75^{\text {th }}\right.$ Anniversary of First Aerial Portugal-Macau Flight]. The stamps public circulation started on 19 April 1999 [24]. At Portugal, both the Portaria [Ministerial Order] No. 334/99 dating back to 13 May 1999 as well as [Ministerial Order] No. 489/99 dating back to 8 July 1999, has authorized special stamps broadcast under the same title (Figure 10) [25].

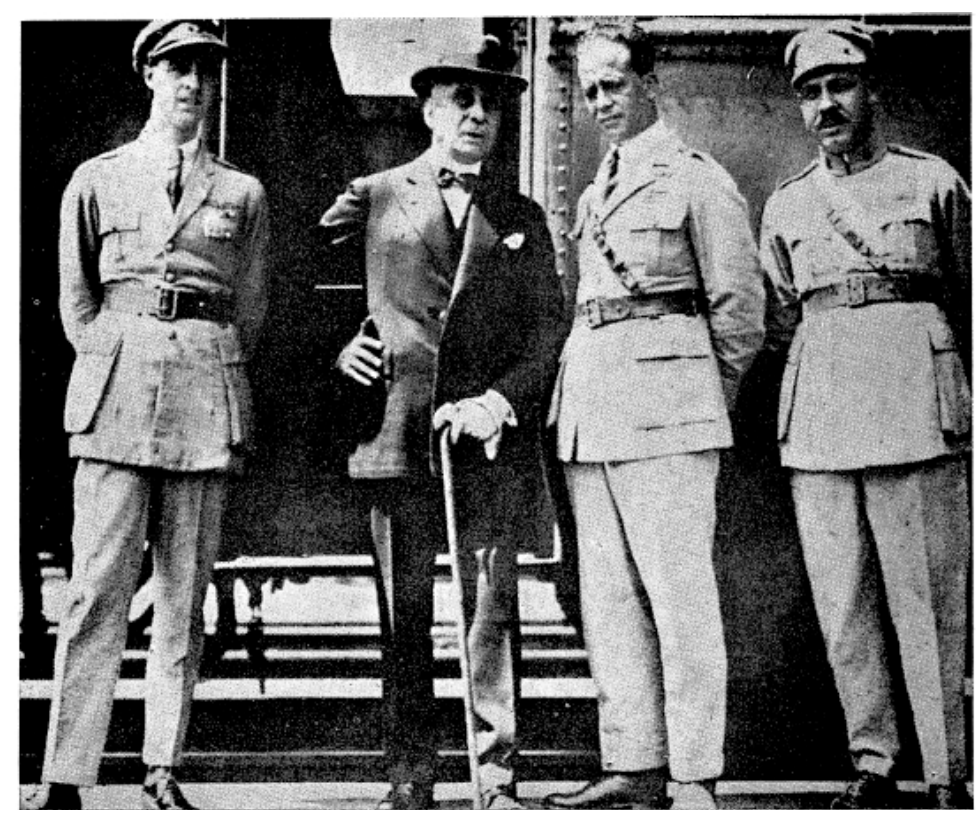

Figure 9. The crew arrival at Boston city with the presence of the Portuguese Ambassador at Washington [1]. 


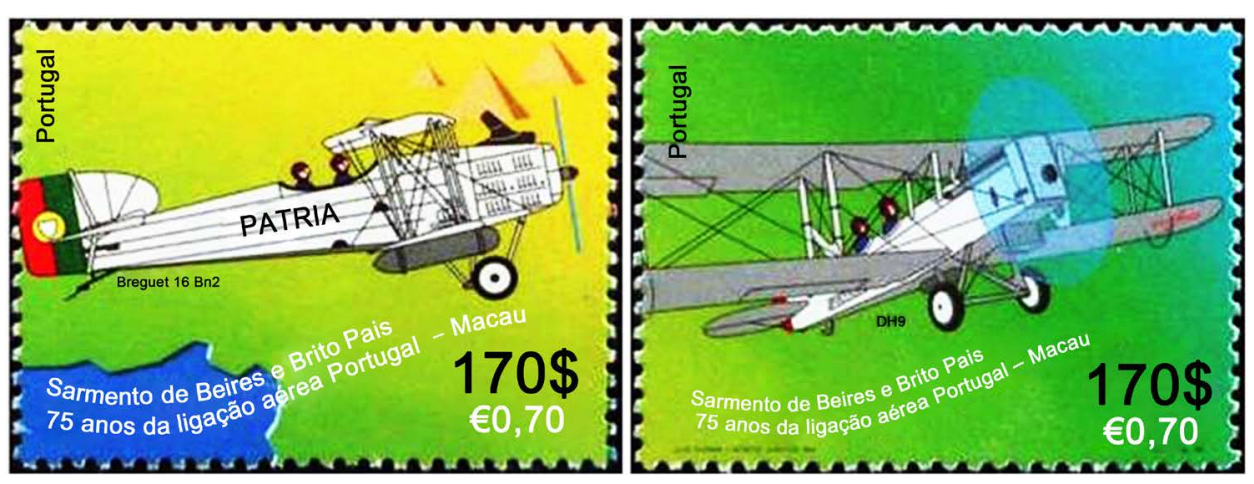

Figure 10. Portuguese stamps launched publically in 1999, paying tribute to the $75^{\text {th }}$ Anniversary of First Aerial Journey from Portugal to Macau.

\section{Conclusion}

In 1920 Brito Pais and Sarmento Beires tried an unsuccessful direct flight attempt from Amadora, Lisbon to Madeira Island aboard the airplane Breguet XIV A2, named " $\mathrm{Ca}$ valeiro Negro". Despite the scarce means of navigation they reach Madeira, which failed to land due to dense fog. In 1922, Gago Coutinho and Sacadura Cabral conducted the First Aerial Cross of the South Atlantic, flying from Lisbon to Rio de Janeiro. The Portuguese Aeronautics rejoiced auspicious days that time, with its aviation pioneers trying consecutively to reach more distant places in intercontinental flights. Supported by the Portuguese Government, in 1923 Gago Coutinho and Sacadura Cabral were contemplating to perform an Around the World Flight. Also in 1924 Brito Pais and Sarmento Beires idealized the conducting of a trip to India and later this project was lengthened to Macau; a trip also with the aspiration of a preparation voyage for a future Portuguese Around the World Flight, a desire chased by Sacadura Cabral. On 7 April 1924, Brito Pais and Sarmento Beires departed from Vila Nova de Milfontes in a Breguet XIV Bn2 airplane, beginning an attempt to fly around the world. On 7 May an engine failure forced them to crash in India. On 30 May they managed to continue the trip in a De Havilland DH9 aircraft model before being forced to end their attempt in 20 June in flying over Macau. Before landing they were caught in some severe winds and crash landing in China near Hong Kong. By order of His Excellency the Governor of Macau, Dr. Rodrigo Rodrigues, the crew of "Pátria" returned to Portugal, via North America, visiting the Portugueses nuclei at Shanghai, Tokyo, some cities in the United States, London and Southampton. Brito Pais, Sarmento Beires and Manuel Gouveia went to Portugal on 9 September and on 14 September the Portuguese people came out to the street to acclaim them. The pilots flew a total of approximately $16,760 \mathrm{~km}$ in 117:41 h, facing often extremely adverse atmospheric conditions, sandstorms and inaccurate navigation maps. The Portuguese Government issued postage stamps commemorating this Voyage. The Portaria [Ordinance] No.90/99/ M from Macau dated on 29 March 1999 has authorized special stamps broadcast entitled "75 Anos da Primeira Ligação Aérea Portugal-Macau" [ $75^{\text {th }}$ Anniversary of First Aerial Portugal-Macau Flight]. The stamps public circulation started on 19 April 1999. At Portugal, both the Portaria 
[Ministerial Order] No. 334/99 dating back to 13 May 1999 as well as [Ministerial Order] No. 489/99 dating back to 8 July 1999, has authorized special stamps broadcast under the same title.

\section{Acknowledgements}

The present work was performed in the scope of the activities of the AeroG-Aeronautics and Astronautics Research Center (http://aeronautics.ubi.pt). The financial support of the Portuguese Ministry of Science through the Science and Technology Foundation (FCT) is gratefully acknowledged.

\section{References}

[1] Beires, J.S. (1953) De Portugal a Macau (A Viagem do "Pátria”). 2nd Edição, Tipografia Domingos de Oliveira, Porto.

[2] Cardoso, E.P.C. (1981) História da Força Aérea Portuguesa. Vol. 2, Edição Cromocolor, Lda, Lisboa, Printed in Gratelo SARL, 2700 Amadora.

[3] Cardoso, E.P.C. (1981) História da Força Aérea Portuguesa. Vol. 1, Edição Cromocolor, Lda, Lisboa, Printed in Gratelo SARL, 2700 Amadora.

[4] Albuquerque, L. (1989) Curso de História da Náutica. Publicações Alfa, Lisboa.

[5] Corrêa, P. (1969) Gago Coutinho, Precursor da Navegação Aérea. Portucalense Editora, Porto.

[6] Corrêa, P. (1964) Sacadura Cabral, Homem e Aviador. Edição do Autor, Printed at Oficinas Bertrand, Lisboa.

[7] Reis, M. and Cortesão, A. (1969) Gago Coutinho Geógrafo, Coimbra, Junta de Investigações do Ultramar, 1970, Sep. de Memórias da Academia das Ciências de Lisboa, Tomo 13.

[8] Cabral, S. (1921) Coutinho-Sacadura Course Corrector. Premier Congrés International de la Navigation Aérienne, Paris, 15-25 November 1921, 112-114.

http://naca.central.cranfield.ac.uk/reports/1922/naca-tm-132.pdf

[9] Barata, J.M.M., Mendes, A.L.M., Morgado, C.M.P., Neves, F.M.S.P. and Silva, A.R.R. (2009) The Origins of Scientific Aircraft Navigation. Proceedings of the 45th AIAA/ASME/SAE/ ASEE Joint Propulsion Conference \& Exhibit and 7 th International Energy Conversion Engineering Conference, 3, 1974-1980. http://arc.aiaa.org/doi/abs/10.2514/6.2009-5022 http://dx.doi.org/10.2514/6.2009-5022

[10] Silva, A.R.R., Morgado, C.M.P., Barata, J.M.M. and Neves, F.M.S.P. (2009) First Flight from Europe to the South Atlantic-Gago Coutinho and Sacadura Cabral. Proceedings of the 47 th AIAA Aerospace Sciences Meeting and the New Horizons Forum and Aerospace Exhibit, 21, 13670-13676. http://arc.aiaa.org/doi/abs/10.2514/6.2009-1162 http://dx.doi.org/10.2514/6.2009-1162

[11] Neves, F.M.S.P., Barata, J.M.M. and Silva, A.R.R. (2010) Gago Coutinho and the Aircraft Navigation. Proceedings of the 48th AIAA Aerospace Sciences Meeting Including the Horizons Forum and Aerospace Exposition, 3, 1823-1832.

http://arc.aiaa.org/doi/abs/10.2514/6.2010-156

http://dx.doi.org/10.2514/6.2010-156

[12] Neves, F.M.S.P., Barata, J.M.M. and Silva, A.R.R. (2016) Sacadura Cabral and the Dawn of PortugueseAviation. Open Journal of Applied Sciences, 6, 16-30.

http://dx.doi.org/10.4236/ojapps.2016.61003 
[13] Neves, F., Barata, J. and Silva, A. (2016) First Aerial South Atlantic Night Crossing. Advances in Historical Studies, 5, 19-35. http://dx.doi.org/10.4236/ahs.2016.51003

[14] Beires, J.S. (1927) Asas que naufragam: De como o avião Argos, ao fim de dezasseis mil quilómetros de vôo, se perdeu ao largo das costas da Clevelândia e do mais que durante a viagem se passou. Livraria Clássica Editorade AM Teixeira \& Co. (Filhos), Lisboa.

[15] Flight-Official Organ of the Royal Aero Club of the United Kingdom (1923) A Portuguese Around-the-World Flight. Vol. 15, No. 761, 26 July 1923, 442.

[16] Flight-Official Organ of the Royal Aero Club of the United Kingdom (1924) Lisbon-Macao Flight. Vol. 16, No. 798, 10 April 1924, 216.

[17] Flight-Official Organ of the Royal Aero Club of the United Kingdom (1924) Lisbon-Macao Flight. Vol. 16, No. 800, 24 April 1924, 233.

[18] Flight-Official Organ of the Royal Aero Club of the United Kingdom (1924) Lisbon-Macao Flight. Vol. 16, No. 801, 1 May 1924, 255.

[19] Flight-Official Organ of the Royal Aero Club of the United Kingdom (1924) Lisbon-Macao Flight. Vol. 16, No. 802, 8 May 1924, 266.

[20] Flight-Official Organ of the Royal Aero Club of the United Kingdom (1924) Lisbon-Macao Flight. Vol. 16, No. 804, 22 May 1924, 289.

[21] Flight-Official Organ of the Royal Aero Club of the United Kingdom (1924) Lisbon-Macao Flight. Vol. 16, No. 806, 5 June 1924, 368.

[22] Flight-Official Organ of the Royal Aero Club of the United Kingdom (1924) Lisbon-Macao Flight. Vol. 16, No. 807, 12 June 1924, 387.

[23] Flight-Official Organ of the Royal Aero Club of the United Kingdom (1924) Lisbon-Macao Flight. Vol. 16, No. 809, 26 June 1924, 413.

[24] http://bo.io.gov.mo/bo/i/99/13/port90.asp

[25] http://filatelica.aac.uc.pt/ANUARIOdeImprensa1999.php

Submit or recommend next manuscript to SCIRP and we will provide best service for you:

Accepting pre-submission inquiries through Email, Facebook, LinkedIn, Twitter, etc.

A wide selection of journals (inclusive of 9 subjects, more than 200 journals)

Providing 24-hour high-quality service

User-friendly online submission system

Fair and swift peer-review system

Efficient typesetting and proofreading procedure

Display of the result of downloads and visits, as well as the number of cited articles

Maximum dissemination of your research work

Submit your manuscript at: http://papersubmission.scirp.org/

Or contact ojapps@scirp.org 